\title{
Pengaruh Kinerja Keuangan Perusahaan Terhadap Devidend Payout Ratio
}

\author{
Iwan Firdaus dan Gean Karlos Purba \\ Facultas Ekonomi dan Bisnis, Universitas Mercu Buana \\ Email: iwanfirdaus08179@gmail.com
}

\begin{abstract}
This research was conducted to examine the effect of Currrent ratio (CR), Return on asset (ROA), Debt to Equity Ratio (DER) and Sales Growth to Dividend Payout Ratio (DPR). The object for this research is pharmaceutical and cosmetics sub-sector listed on the Indonesia Stock Exchange in the period 2012-2016. This research was conducted using quantitative menthod with total 30 sample of research were determined by saturated sampling. Method of hypothesis testing using $t$-test. This research use Currrent ratio $\left(X_{1}\right)$, Return on asset $\left(X_{2}\right)$, Debt to Equity Ratio $\left(X_{3}\right)$, Sales Growth $(X 4)$ as independent variable and Dividend Payout Ratio as dependent variable. The results of this research is Return on asset positive and has significant effect to Dividend Payout Ratio, for Currrent ratios and Sales Growth a positive but significant effect on Dividend Payout Ratio, whlile the Debt to Equity Ratio positive and has no significant effect to Dividend Payout Ratio.
\end{abstract}

Keywords: Currrent ratio, Return on asset, Debt to Equity Ratio, Sales Growth and Dividend Payout Ratio.

Abstrak: Penelitian ini dilakukan untuk menguji pengaruh variabel Currrent ratio (CR), Return on asset (ROA), Debt to Equity Ratio (DER) dan Sales Growth terhadap Dividend Payout Ratio (DPR). Objek penelitian ini adalah sub sektor farmasi dan kosmetik yang terdaftar di Bursa Efek Indonesia periode 2012-2016. Penelitian ini dilakukan menggunakan metode kuantitatif dengan total 30 sampel penelitian yang ditentukan melalui metode sample jenuh. Metode pengujian hipotesis menggunakan uji t. Variabel yang digunakan dalam penelitian ini adalah Current ratio $\left(\mathrm{X}_{1}\right)$, Return on asset $\left(\mathrm{X}_{2}\right)$, Debt to Equity Ratio $\left(\mathrm{X}_{3}\right)$, Sales Growth (X4) sebagai variabel independen dan Dividend Payout Ratio sebagai variabel dependen. Hasil penelitian ini adalah Return on asset berpengaruh positif dan signifikan terhadap Dividend Payout Ratio, untuk Currrent ratio dan Sales Growth berpengaruh positif tapi signifikan terhadap Dividend Payout Ratio, sedangkan Debt to Equity ratio berpengaruh negatif dan tidak signifikan terhadap Dividend Payout Ratio.

Kata Kunci: Currrent ratio, Return on asset, Debt to Equity Ratio, Sales Growth dan Dividend Payout Ratio.

\section{PENDAHULUAN}

Industri Farmasi berperan dalam melakukan kegiatan pembuatan obat atau bahan obat. Pembuatan obat meliputi seluruh tahapan kegiatan dalam menghasilkan obat, yang meliputi pengadaan bahan awal dan bahan pengemas, produksi, pengemasan, pengawasan mutu dan pemastian mutu sampai diperoleh obat untuk didistribusikan. Selain pembuatan 
obat, industri farmasi juga berperan dalam pendidikan dan pelatihan, penelitian dan juga pengembangan obat, hal ini tertuang dalam Peraturan Menteri Kesehatan Republik Indonesia Nomor 1799 MENKES/PER/XII/2010. Potensi pertumbuhan industri farmasi di Indonesia diprediksi akan melaju tinggi kedepannya, hal ini dikarenakan implementasi BPJS Kesehatan yang semakin baik dan luas, jumlah penduduk Indonesia yang besar, pertumbuhan masyarakat kelas menengah keatas, serta peningkatan kesadaran masyarakat akan pentingnya menjaga kesehatan diharapkan menjadi penggerak utama pertumbuhan disektor industri farmasi. Selain itu, berdasarkan Rencana Induk Pembangunan Industri Nasional (RIPIN) tahun 2015-2035, industri farmasi dan bahan farmasi merupakan salah satu sektor andalan yang berperan besar sebagai penggerak utama perekonomian di masa yang akan datang. Menurut menteri perindustrian, (Hartanto, 2017), nilai pasar produk farmasi di Indonesia sekitar USD 4,7 milIar atau setara dengan 27\% dari total pasar farmasi di ASEAN. Bedasarkan data Mandiri institute (2016), pasar farmasi nasional tumbuh rata-rata $10 \%$ per tahun pada periode 2011-2015. Besar pasar farmasi nasional pada tahun 2016 diperkirakan sekitar 69 triliun rupiah dan akan meningkat menjadi 102 triliun rupiah pada 2020. Pada tahun 2015, obat resep (ethical) mendominasi sekitar $62 \%$ pasar farmasi nasional dan sisanya adalah obat bebas (over the counter).

Selain pertumbuhan positif yang terdapat pada industri farmasi, kemajuan pada industri kecantikan (kosmetik) di Indonesia saat ini juga menunjukkan peningkatan. Berdasarkan data (Kementerian Perindustrian, 2016), pertumbuhan pasar industri ini ratarata mencapai 9,67\% per tahun dalam enam tahun terakhir (2009-2015). Jumlah penduduk Indonesia diproyeksi akan menembus angka 271 jutaan pada tahun 2020. Jumlah tersebut meningkat sekitar 4,8\% dibandingkan dengan total populasi penduduk Indonesia tahun 2016. Dengan angka pertumbuhan yang cukup besar tersebut, maka Indonesia merupakan pasar yang sangat potensial bagi perusahaan kosmetik. Kementerian perindustrian bahkan menyebutkan nilai industri kosmetik ditaksir bisa mencapai Rp100 triliun. Indonesia diprediksi akan menjadi salah satu pasar kosmetik yang paling cepat bertumbuh di kawasan Asia.

Melihat besarnya potensi bisnis yang ada pada industri farmasi dan kosmetik, tentu menjadi daya tarik tersendiri bagi para investor untuk menanamkan modalnya pada perusahaan farmasi dan kosmetik yang ada di Indonesia, karena pada umumnya investor mempunyai tujuan utama dalam menanamkan modalnya ke dalam perusahaan yaitu untuk mencari pendapatan atau tingkat kembalian investasi (return) baik berupa pendapatan dividen (dividend yield) maupun pendapatan dari selisih harga jual saham terhadap harga belinya (capital gain). Namun, dibalik kinerja yang positif dan potensi besar di masa yang akan datang, industri farmasi dan kosmetik Indonesia masih sangat bergantung pada bahan baku impor, hampir 95\% bahan baku obat (BBO) diperoleh dari hasil impor. www.kimiafarma.co.id (2017), dan 90\% pasokan bahan baku kosmetik dalam negeri juga masih bergantung dari hasil impor. www.mediaindonesia.com (2016). Kondisi ini menyebabkan industri farmasi sangat rentan terhadap fluktuasi kurs, yang mana akan berpengaruh terhadap laba yang diperoleh perusahaan. Pelemahan kurs akan membuat biaya impor bahan baku akan semakin meningkat yang dapat menekan laba bersih perusahaan dan nilai dividen yang akan dibagikan kepada pemegang saham setiap tahunnya.

Tabel 1. Rata - Rata Dpr Pada Industri Farmasi Dan Kosmetik Yang Terdaftar Di Bursa Efek Indonesia Periode 2012 -2016 
Firdaus dan Purba: Pengaruh Kinerja Keuangan Perusahaan Terhadap Devidend...

\begin{tabular}{|c|c|c|c|c|c|c|}
\hline KODE & Emiten & 2012 & 2013 & 2014 & 2015 & 2016 \\
\hline DVLA & $\begin{array}{l}\text { Darya-Varia } \text { Laboratoria } \\
\text { Tbk. }\end{array}$ & $23,69 \%$ & $41,85 \%$ & $30,45 \%$ & $72,40 \%$ & $25,68 \%$ \\
\hline KLBF & Kalbe Farma Tbk. & $54,35 \%$ & $48,96 \%$ & $37,57 \%$ & $37,88 \%$ & $43,28 \%$ \\
\hline KAEF & $\begin{array}{l}\text { Kimia Farma (Persero) } \\
\text { Tbk. }\end{array}$ & $16,70 \%$ & $14,27 \%$ & $22,86 \%$ & $17,67 \%$ & $18,32 \%$ \\
\hline MERK & Merck Tbk. & $80,14 \%$ & $74.18 \%$ & $95,15 \%$ & $145,98 \%$ & $31,43 \%$ \\
\hline TSPC & Tempo Scan Pacific Tbk. & $53,13 \%$ & $52,86 \%$ & $57,76 \%$ & $54,42 \%$ & $41,25 \%$ \\
\hline TCID & Mandom Indonesia Tbk. & $49,47 \%$ & $46,45 \%$ & $42,68 \%$ & $50,87 \%$ & $14,40 \%$ \\
\hline \multicolumn{2}{|c|}{ RATA-RATA } & $46.25 \%$ & $34.07 \%$ & $47.75 \%$ & $63.20 \%$ & $29.06 \%$ \\
\hline
\end{tabular}

Sumber: (idx.co.id, data diolah, 2018)

Data pada Tabel 1 menunjukkan PT Darya-Varia Laboratoria Tbk dalam 5 tahun terakhir secara konsisten selalu membagikan dividen kepada pemegang saham setiap tahunnya. Pada periode 2012 sampai 2015 rasio pembayaran dividen mengalami peningkatan yang cukup signifikan meskipun pada tahun 2014 terjadi sedikit penurunan. Terjadinya penurunan rasio pembayaran deviden pada tahun 2014 sebagai dampak dilakukannya merger dengan PT Prafa, selain itu bersama Unilab Biosciences Corporation Hong Kong, perusahaan afiliasinya, PT Darya-Varia Laboratoria mendirikan anak usaha baru dengan nama PT Unilab Biosciences pada tanggal 24 April 2014. Setelah mengalami peningkatan rasio pembayaran dividen yang cukup signifikan pada tahun 2015, terjadi penurunan yang cukup tajam terhadap rasio pembayaran dividen pada tahun 2016 meskipun laba yang diperoleh lebih besar dari tahun sebelumnya, hal ini disebakan adanya penggunaan dana yang cukup besar untuk pembelian aset tetap dan penyetoran tambahan modal kepada PT. Etana Biotechnologies (sebelumnya bernama PT Unilab Biosciences).

PT Merck Tbk pada tahun 2012 hingga 2014 mengalami peningkatan dalam rasio pembayaran dividen, namun pada tahun 2015 terjadi penurunan yang signifikan, hal ini disebabkan adanya penambahan beberapa produk baru untuk memperkaya jajaran produk yang ada, termasuk neurobion injection dual ampoule yang hadir dengan konsep baru, lalu sangobion fit dan sangobion vita-tonic, sehingga semakin memperluas akses pasar bagi produk bebas Merck. Pada tahun 2015 perusahaan juga memulai proyek renovasi pabrik yang akan menaikkan kapasitas produksi tablet dan kapsul (produk solid) sebesar 35\%. Beberapa mesin baru juga ditambahkan untuk mendukung proses produksi pabrik, yaitu antara lain mesin blistering pack, sugar coating dan final mixer. Berdasarkan hasil rapat umum pemegang saham (RUPS), diputuskan untuk menahan laba yang lebih besar untuk digunakan membiayai proyek-proyek baru, strategi dan kampanye pemasaran, serta belanja modal dan pengembangan bisnis lebih lanjut. 


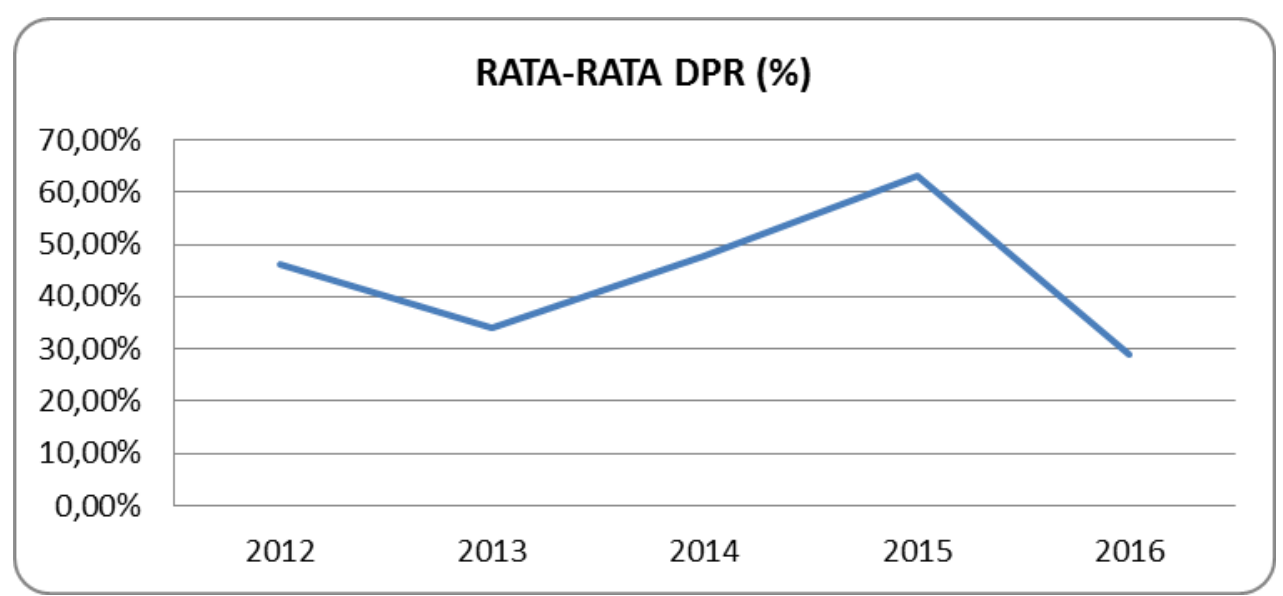

Gambar 1. Rata-rata DPR Industri Farmasi dan Kosmetik yang Terdaftar di Bursa Efek Indonesia Tahun 2012-2016

Sumber: (idx.co.id, data diolah, 2018)

Banyak faktor yang dapat mempengaruhi kinerja sebuah perusahaan yang dapat berpengaruh terhadap kebijakan dividen seperti situasi politik, keamanan, kebijakan perusahaan, pertumbuhan ekonomi, perubahan kurs, inflasi dan lain-lain. Gambar 1.1 menunjukkan secara garis besar rata-rata DPR industri farmasi dan kosmetik mengalami fluktuasi dari tahun 2012 sampai tahun 2016, hingga mengalami penurunan yang cukup signifikan pada tahun 2016, hal ini disebabkan karena perlambatan pertumbuhan ekonomi dunia yang juga berdampak pada perekonomian Indonesia. Menurut data Badan Pusat Statistik (BPS), pertumbuhan ekonomi Indonesia terus mengalami penurunan dari tahun 2013 hingga 2015, di mana pada tahun 2013 mencapai 5,78\% hingga mencapai titik terendahnya pada tahun 2015 sebesar 4,9\%, (terendah dalam 6 tahun terakhir). Hal ini berbanding lurus dengan menurunnya rata-rata rasio dividen yang dibagikan oleh perusahaan kepada pemegang saham. Menurunnya rata-rata rasio dividen pada industri farmasi dan kosmetik juga dipengaruhi oleh pelemahan nilai kurs rupiah terhadap mata uang asing terutama terhadap US Dollar, dimana pada tahun 2012 rata-rata nilai tukar rupiah terhadap Dollar berada pada Rp 9.670 per USD dan pada tahun 2013 nilai tukar rupiah melemah menjadi Rp 12.189 per USD dan terus berlanjut hingga tahun 2015 mencapai 13.795 per USD. Melemahnya nilai tukar rupiah terhadap mata uang asing menempatkan industri farmasi di Indonesia dalam keadaan tertekan akibat tingginya biaya impor bahan baku, sebagaimana diketahui $95 \%$ bahan baku obat masih mengandalkan impor dari luar negeri.

Berikut ini ditampilkan beberapa research gap yang berkaitan dengan kebijakan dividen yang dilakukan oleh peneliti terdahulu. Hasil penelitian yang dilakukan oleh (Afrina, 2014) menunjukkan bahwa current ratio memiliki pengaruh positif dan signifikan terhadap dividend payout ratio. Hal ini bertentangan dengan hasil penelitian yang dilakukan oleh (Pamungkas et al., 2017) menyatakan adanya pengaruh negatif dan signifikan antar variabel current ratio dengan variabel dividend payout ratio. Sementara itu penelitian lain yang dilakukan oleh (Arilaha, 2009) yang menyatakan bahwa likuiditas perusahaan memiliki pengaruh yang positif dan tidak signifikan terhadap dividend payout ratio.

Penelitian yang dilakukan oleh (Alzomaia dan Al-Khadiri, 2013) menemukan bahwa variabel return on asset memiliki pengaruh positif dan signifikan terhadap dividend 
payout ratio, sementara penelitian yang dilakukan oleh (Yanti, 2014) menyatakan variabel return on asset memiliki pengaruh negatif dan signifikan terhadap dividend payout ratio. Berbeda dengan hasil penelitian (Deitiana, 2009) yang menyatakan bahwa return on asset memiliki pengaruh positif dan tidak signifikan terhadap dividend payout ratio. (Rahyuda, 2017) dalam penelitiannya menyebutkan adanya pengaruh positif dan signifikan antara variabel debt to equity ratio dengan variabel dividend payout ratio. Sementara penelitian yang dilakukan oleh (Dewi, 2008) menyebutkan bahwa variabel debt to equity ratio memiliki pengaruh negatif dan signifikan terhadap dividend payout ratio. Hal ini tidak sesuai dengan hasil penelitian yang dilakukan oleh (Sumiati, 2013) yang menyatakan bahwa financial leverage memiliki hubungan positif dan tidak signifikan terhadap kebijakan dividen.

Dalam penelitian yang dilakukan oleh (Asih, 2015) mengemukakan bahwa sales growth memiliki hubungan positif dan signifikan terhadap dividend payout ratio. Melalui penelitiannya (Ojeme dan Urhoghide, 2016) menyatakan bahwa sales growth memiliki pengaruh negatif dan signifikan terhadap dividend payout ratio. Hal ini bertentangan dengan hasil penelitian dari (Hamidah, 2014) di mana sales growth tidak berpengaruh terhadap dividend payout

Melihat fenomena Dividend Payout Ratio (DPR) dalam kaitannya dengan rasiorasio keuangan, maka penelitian ini diberi judul "pengaruh variabel Currrent ratio (CR), Return on asset (ROA), Debt to Equity Ratio (DER) dan Sales Growth terhadap Dividend Payout Ratio (DPR). sub sektor farmasi dan kosmetik yang terdaftar di Bursa Efek Indonesia periode 2012-2016".

Berdasarkan uraian-uraian diatas, diajukan pertanyaaan rumusan masalah sebagai berikut: (1) Apakah ada pengaruh current ratio (CR) terhadap dividend payout ratio (DPR) pada industri farmasi dan kosmetik yang terdaftar di BEI periode 2012-2016?; (2) Apakah ada pengaruh return on asset (ROA) terhadap dividend payout ratio (DPR) pada industri farmasi dan kosmetik yang terdaftar di BEI periode 2012-2016?; (3) Apakah ada pengaruh debt to equity ratio (DER) terhadap dividend payout ratio (DPR) pada industri farmasi dan kosmetik yang terdaftar di BEI periode 2012-2016?; (4) Apakah ada pengaruh sales growth terhadap dividend payout ratio (DPR) pada industri farmasi dan kosmetik yang terdaftar di BEI periode 2012-2016?

Tujuan penelitian ini adalah memberi jawaban atas pertanyaan rumusan masalah yang ada. Adapun tujuan dari penelitian, antara lain: (1) Untuk mengetahui pengaruh current ratio (CR) terhadap dividend payout ratio (DPR) pada industri farmasi dan kosmetik yang terdaftar di BEI periode 2012-2016; (2) Untuk mengetahui pengaruh return on asset (ROA) terhadap dividend payout ratio (DPR) pada industri farmasi dan kosmetik yang terdaftar di BEI periode 2012-2016; (3) Untuk mengetahui pengaruh debt to equity ratio (DER) terhadap dividend payout ratio (DPR) pada industri farmasi dan kosmetik yang terdaftar di BEI periode 2012-2016; (4) Untuk mengetahui pengaruh sales growth (SG) terhadap dividend payout ratio (DPR) pada industri farmasi dan kosmetik yang terdaftar di BEI periode 2012-2016.

\section{KAJIAN TEORI}

Rasio pembayaran dividen (dividend payout ratio). Menurut (Brigham and Houston, 2014) Harga saham didasarkan pada arus kas yang diharapkan pada tahun-tahun mendatang, bukan hanya ditahun berjalan. Jadi, memaksimilisasi harga saham meminta 
kita untuk melihat operasi secara jangka panjang. Rasio pembayaran dividen (dividend payout ratio) merupakan perbandingan antara dividen dengan earning per share yang dihasilkan oleh perusahaan. Rumus dividend payout ratio adalah sebagai berikut:

$$
\text { Dividend Payout Ratio }=\frac{\text { Dividen per lembar }}{\text { Laba per lembar }} \text {. }
$$

Current ratio (CR). Rasio lancar (current ratio) merupakan rasio untuk mengukur kemampuan perusahaan membayar kewajiban jangka pendek atau utang yang segera jatuh tempo pada saat ditagih secara keseluruhan. Dengan kata lain, seberapa banyak aktiva lancar yang tersedia untuk menutupi kewajiban jangka pendek yang segera jatuh tempo. Rasio lancar dapat pula dikatakan sebagai bentuk untuk mengukur tingkat keamanan (margin of safety) suatu perusahaan. Secara sistematis, rasio lancar (current ratio) dapat dirumuskan sebagai berikut:

$$
\text { Current Ratio }=\frac{\text { Aset Lancar }}{\text { Utang Lancar }}
$$

Return on asset (ROA). Return on asset merupakan rasio kemampuan perusahaan dalam menghasilkan laba bersih dari total asset yang dimilikinya. Rasio ini penting bagi pihak manajemen untuk mengevaluasi profitabilitas perusahaan dalam mengelola total aktiva perusahaan. Semakin besar return on asset, berarti semakin baik perusahaan dalam mengelola aktiva untuk menghasilkan laba yang lebih besar. Rumus, return on asset adalah sebagai berikut:

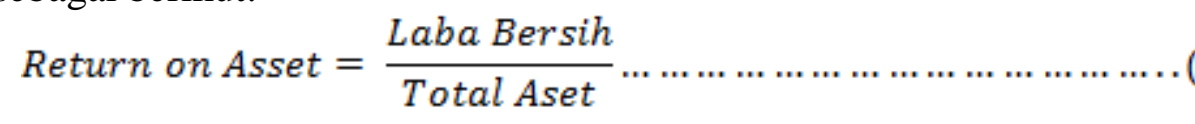

Debt to equity ratio (DER). Merupakan rasio yang digunakan untuk menilai utang dengan ekuitas. Untuk mencari rasio ini, dengan cara membandingkan seluruh utang, termasuk utang lancar dengan seluruh ekuitas. Rasio ini berguna untuk mengetahui jumlah dana yang disediakan kreditor dengan pemilik perusahaan. Dengan kata lain rasio ini untuk mengetahui setiap rupiah modal sendiri yang dijadikan jaminan untuk utang. Secara sistematis, debt to equity ratio dapat dirumuskan sebagai berikut:

$$
\text { Debt to Equity Ratio }=\frac{\text { Total Utang }}{\text { Total Ekuitas }}
$$

Sales growth (SG). Growth adalah Rasio pertumbuhan (growth ratio) merupakan rasio yang menggambarkan kemampuan perusahaan mempertahankan posisi ekonominya di tengah pertumbuhan perekonomian dan sektor usahanya. Kasmir (2014). Sales growth adalah pertumbuhan penjualan perusahaan di mana dana yang diperoleh dari penjualan merupakan aktiva yang digunakan untuk aktivitas operasional perusahaan. Semakin besar penjualan maka diharapkan semakin besar pula hasil operasional yang dihasilkan oleh suatu perusahaan.

$$
\text { Sales growth }=\frac{\text { Penjualan tahun ini }- \text { Penjualan tahun lalu }}{\text { Penjualan tahun lalu }}
$$

\section{Rerangka konseptual}




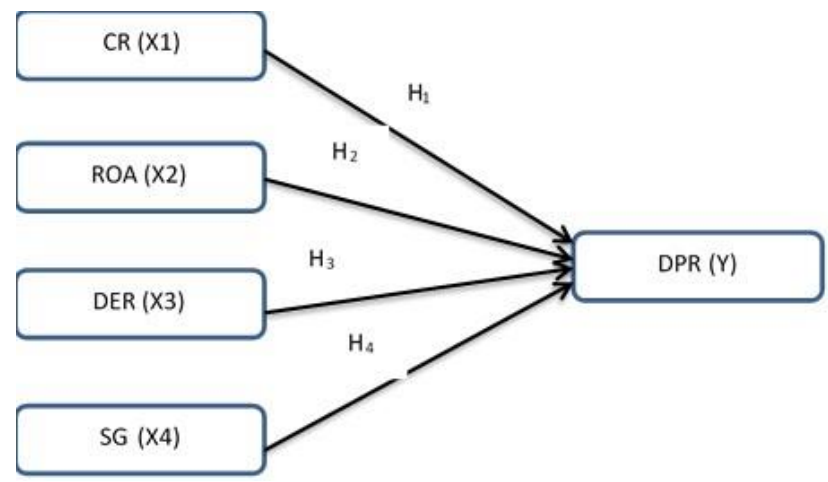

Gambar 1. Rerangka Konseptual

Sumber: (berbagai sumber diolah, 2018)

Hipotesis. Menurut Sugiyono (2014) hipotesis penelitian merupakan dugaan sementara yang digunakan sebelum dilakukannya penelitian. Hipotesis penelitian adalah jawaban sementara terhadap masalah yang diteliti, dimana kebenarannya perlu diuji secara empiris. Hipotesis penelitian ini adalah sebagai berikut:

1) $\mathrm{H}_{1}$ : Current ratio $(\mathrm{CR})$ berpengaruh positif dan signifikan terhadap dividend payout ratio (DPR).

2) $\mathrm{H}_{2}$ : Return on asset (ROA) berpengaruh positif dan signifikan terhadap dividend payout ratio (DPR).

3) $\mathrm{H}_{3}$ : Debt to equity ratio (DER) berpengaruh negatif dan signifikan terhadap dividend payout ratio (DPR).

4) $\mathrm{H}_{4}$ : Sales growth (SG) berpengaruh positif dan signifikan terhadap dividend payout ratio (DPR).

\section{METODE}

Desain penelitian yang digunakan adalah penelitian kausal. Menurut Sugiyono (2014) penelitian kausal merupakan penelitian untuk mengetahui pengaruh antara satu arah atau lebih variabel bebas (independent variabel) terhadap variabel terikat (dependent variabel), yaitu untuk mengetahui pengaruh variabel Currrent ratio (CR), Return on asset (ROA), Debt to Equity Ratio (DER) dan Sales Growth terhadap Dividend Payout Ratio (DPR). sub sektor farmasi dan kosmetik yang terdaftar di Bursa Efek Indonesia periode 2012-2016.

Menurut (Sugiyono, 2014) variabel adalah segala sesuatu yang berbentuk apa saja yang ditetapkan oleh peneliti untuk dipelajari sehingga diperoleh informasi tentang hal tersebut, kemudian ditarik kesimpulannya.

Variabel dependen adalah variabel yang menjadi fokus utama dalam penelitian ini. Variabel ini sering disebut sebagai variabel output, criteria, konsekuen. Dalam bahasa Indonesia disebut juga sebagai variabel terikat. Variabel dependen yang digunakan dalam penelitian ini adalah adalah kebijakan dividen (Y) yang diukur dengan dividend payout ratio (DPR). Secara matematis rumus dividend payout ratio (DPR) dapat dirumuskan sebagai berikut: 


$$
\text { Dividend Payout Ratio }=\frac{\text { Dividen per saham }}{\text { Laba per saham }}
$$

Variabel independen

1. Current ratio (CR). Rasio lancar (Current Ratio) merupakan rasio untuk mengukur kemampuan perusahaan membayar kewajiban jangka pendek atau utang yang segera jatuh tempo pada saat ditagih secara keseluruhan. Dengan kata lain, seberapa banyak aktiva lancar yang tersedia untuk menutupi kewajiban jangka pendek yang segera jatuh tempo. Rasio lancar dapat pula dikatakan sebagai bentuk untuk mengukur tingkat keamanan (margin of safety) suatu perusahaan. Kasmir (2014). Secara matematis rumus Current Ratio (CR) dapat dirumuskan sebagai berikut:

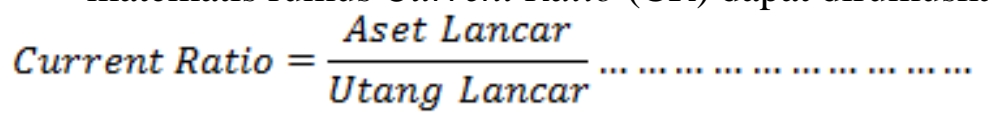

2. Return on asset (ROA). ROA menunjukkan kemampuan perusahaan dalam menghasilkan laba bersih dari penggunaan total asset yang dimiliki. Rasio ini penting bagi pihak manajemen untuk menunjukkan kinerja perusahaan yang lebih baik dalam hal profitabilitas perusahaan. Semakin besar ROA, berarti semakin besar laba yang dihasilkan. Kasmir (2014). Secara matematis rumus Return on Asset (ROA) dapat dirumuskan sebagai berikut:

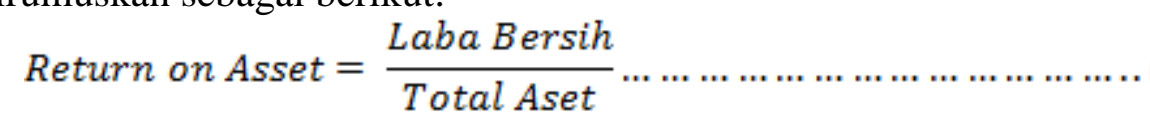

3. Debt to equity ratio (DER). Merupakan rasio yang digunakan untuk menilai utang dengan ekuitas. Untuk mencari rasio ini, dengan cara membandingkan seluruh utang, termasuk utang lancar dengan seluruh ekuitas. Rasio ini berguna untuk mengetahui jumlah dana yang disediakan kreditor dengan pemilik perusahaan. Dengan kata lain rasio ini untuk mengetahui setiap rupiah modal sendiri yang dijadikan jaminan untuk utang. Kasmir (2014). Secara matematis rumus debt to equity ratio (DER) dapat dirumuskan sebagai berikut:

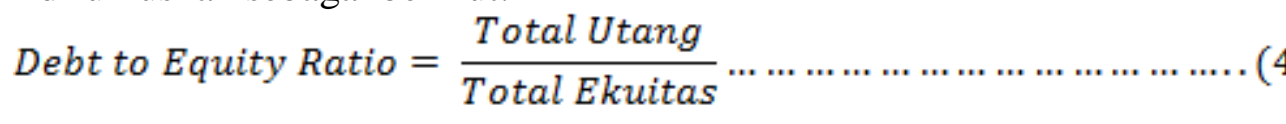

4. Sales growth (SG). Sales growth adalah pertumbuhan penjualan perusahaan dimana dana yang diperoleh dari penjualan merupakan aktiva yang digunakan untuk aktivitas operasional perusahaan. Semakin besar penjualan maka diharapkan semakin besar pula hasil operasional yang dihasilkan oleh suatu perusahaan. Secara matematis rumus sales growth dapat dirumuskan sebagai berikut:

$$
\text { Sales growth }=\frac{\text { Sales tahun ini }- \text { Sales tahun lalu }}{\text { Sales tahun lalu }}
$$

Populasi dan Sampel Penelitian. Populasi dalam penelitian ini adalah perusahaan industri farmasi dan kosmetik yang terdaftar dalam Bursa Efek Indonesia periode 20122016 dengan kriteria memiliki data lengkap setiap tahun, tidak memiliki variabel negatif dan data bersifat normal sesuai dengan variabel dependen dan independen, maka jumlah 
populasi sebanyak 6 perusahaan selama 5 tahun pengamatan, sehingga populasi berjumlah 30 pengamatan. Menurut (Sugiyono, 2014) sampel adalah bagian dari jumlah dan karakteristik yang dimiliki oleh populasi. Metode yang digunakan adalah sample jenuh yang bertujuan untuk mendapatkan sampel yang sesuai dengan populasi. Sampel dalam penelitian ini berjumlah 6 perusahaan dengan tahun pengamatan 5 tahun, sehingga sampel berjumlah 30 data.

Teknik Pengumpulan Data. Dalam penelitian ini penulis menggunakan teknik pengumpulan data dengan studi kepustakaan. Jenis data yang digunakan dalam penelitian ini adalah data sekunder. Data sekunder adalah data yang sudah diolah, diperoleh berdasarkan laporan tahunan yang telah diaudit dan dipublikasikan. Menurut (Sugiyono, 2014) data sekunder adalah sumber data yang secara tidak langsung memberikan data kepada pengumpul data, seperti dokumen. Data sekunder yang digunakan dalam penelitian ini mencakup data laporan keuangan tahunan perusahaan sub sektor Otomotif dan Komponen yang tercatat dalam Bursa Efek Indonesia selama periode penelitian yaitu 2012 sampai dengan 2016, serta bahan pustaka lainnya yaitu jurnal, buku, dan penelitian terdahulu.

Metode Analisis. Menurut (Winarno, 2015) metode analisis yang digunakan dalam penelitian ini adalah analisis regresi data panel dengan bantuan software eviews 9. EViews adalah program komputer yang digunakan untuk mengolah data statistika dan data ekonometrika, EViews dapat digunnakan untuk menyelesaikan masalah-masalah yang berbentuk time series, cross section, maupun data panel. (Winarno, 2015) data panel adalah bentuk khusus dari pooled data. Secara sederhana, pooled data adalah kombinasi antara data time series dan data cross section.

\section{HASIL DAN PEMBAHASAN}

\section{Hasil Statistik Deskriptif}

Tabel 2. Statistik Deskriptif

Date: $08 / 13 / 18$

Time: $01: 38$

Sample: 20122016

\begin{tabular}{lccccc}
\hline \hline & DPR & CR & ROA & DER & GROWTH \\
\hline \hline Mean & 46.53067 & 3.553667 & 13.68133 & 37.62167 & 9.260333 \\
Median & 42.98000 & 3.460000 & 11.36500 & 35.42000 & 9.350000 \\
Maximum & 145.9800 & 7.720000 & 40.59000 & 103.0700 & 28.40000 \\
Minimum & 14.27000 & 1.710000 & 5.890000 & 15.02000 & -27.70000 \\
Std. Dev. & 27.55420 & 1.236230 & 7.256862 & 17.09006 & 10.11975 \\
Skewness & 1.666966 & 1.192657 & 1.899313 & 2.071232 & -1.299341 \\
Kurtosis & 6.864361 & 5.461865 & 7.411692 & 8.437813 & 7.257837 \\
Sum & 1395.920 & 106.6100 & 410.4400 & 1128.650 & 277.8100 \\
Sum Sq. Dev. & 22017.79 & 44.31970 & 1527.199 & 8470.037 & 2969.869
\end{tabular}

Jurnal Ekonomi/Volume XXIV, No. 01 Maret 2019: 31-45 


\begin{tabular}{llllll} 
Observations & 30 & 30 & 30 & 30 & 30 \\
\hline \hline
\end{tabular}

Sumber: (data BEI diolah Eviews 9, 2018)

Berdasarkan kepada Tabel 2 di atas, terlihat Dividend Payout Ratio (DPR) memiliki nilai mean sebesar 46,53067 dengan nilai tertinggi sebesar 145,98 dan harga saham terendah sebesar 14,27. Current Ratio (CR) memiliki nilai mean sebesar 3,553667 dengan nilai tertinggi sebesar 7,72 dan nilai terendah sebesar 1,71. Return on Asset (ROA) memiliki nilai mean sebesar 13,68133 dengan nilai tertinggi sebesar 40,59 dan nilai terendah sebesar 5,89. Debt to equity ratio (DER) memiliki nilai mean sebesar 37,62167 dengan nilai tertinggi yaitu 103,07 dan nilai terendah sebesar 15,02. Sales Growth (SG) memiliki nilai mean sebesar 9,260333 dengan nilai tertinggi yaitu 28,4 dan nilai terendah sebesar $-27,7$.

Uji common effect. Pendekatan common effect ini merupakan pendekatan yang paling sederhana untuk mengestimasi parameter model data panel, yaitu dengan mengkombinasikan data cross section dan time series sebagai satu kesatuan dan tanpa melihat adanya perbedaan waktu dan individu. Dari pengolahan Eviews 9.0 didapatkan hasil sebagai berikut:

Tabel 3. Hasil Uji Common Effect

Dependent Variable: DPR?

Method: Pooled Least Squares

Date: 08/13/18 Time: 20:23

Sample: 20122016

Included observations: 5

Cross-sections included: 6

Total pool (balanced) observations: 30

\begin{tabular}{crlll}
\hline \hline \multicolumn{1}{c}{ Variable } & Coefficient & Std. Error & t-Statistic & Prob. \\
\hline \hline CR? & -0.239234 & 5.324859 & -0.044928 & 0.9645 \\
ROA? & 2.041921 & 0.684068 & 2.984966 & 0.0063 \\
DER? & -0.120496 & 0.395321 & -0.304806 & 0.7630 \\
GROWTH? & 0.052386 & 0.469419 & 0.111597 & 0.9120 \\
C & 23.49278 & 34.81899 & 0.674712 & 0.5061 \\
\hline \hline R-squared & 0.315293 & Mean dependent var & 46.53067 \\
Adjusted R-squared & 0.205740 & S.D. dependent var & 27.55420 \\
S.E. of regression & 24.55666 & Akaike info criterion & 9.390855 \\
Sum squared resid & 15075.73 & Schwarz criterion & 9.624388 \\
Log likelihood & -135.8628 & Hannan-Quinn criter. & 9.465564 \\
F-statistic & 2.877992 & Durbin-Watson stat & 1.706063 \\
Prob(F-statistic) & 0.043415 & & & \\
\hline \hline
\end{tabular}

Sumber: (data BEI diolah Eviews 9, 2018) 
Berdasarkan Tabel 3 hasil uji common effect, di dapat persamaan sebagai berikut:

$$
\text { Harga saham }=\mathrm{C}-0,044928 \mathrm{CR}+2,984966 \mathrm{ROA}-0,304806 \mathrm{DER}+0,111597 \mathrm{GS}
$$

Merujuk kepada Tabel 3 di atas, didapatkan hasil adjuster $R$-squared dengan nilai 0,205740 atau 20,574 persen. Sehingga dapat dikatakan bahwa variabel-variabel bebas dalam penelitian ini dapat memepengaruhi variabel terikatnya sebesar 20,574 persen sedangkan sisanya 79,43 persen dijelaskan oleh variable lain di luar penelitian.

Pengujian hipotesis. Uji t. Berdasarkan Tabel 3 hasil uji random effect yang memuat hasil uji t dengan melihat nilai $t$-statistic dan probabilitas dapat dijelaskan sebagai berikut:

1) Pengaruh Current Ratio (CR) terhadap Dividend Payout Ratio (DPR)

Menurut tabel 4.2 variabel current ratio (CR) berpengaruh positif dan tidak signifikan terhadap dividend payout ratio (DPR). Menurut (Kasmir, 2014), current ratio (CR) merupakan rasio untuk mengukur kemampuan perusahaan membayar kewajiban jangka pendek atau utang yang segera jatuh tempo pada saat ditagih secara keseluruhan. Hasil penelitian ini didukung oleh (Arilaha, 2009), (Maldjian dan khoury, 2014), (Mubarok, 2016)

2) Pengaruh Return on Asset (ROA) terhadap Dividend Payout Ratio (DPR)

Menurut tabel 4.2 variabel return on asset (ROA) berpengaruh positif dan signifikan terhadap dividend payout ratio (DPR). Bird in the hand theory, (Brigham dan Houston, 2014) bahwa keyakinan para investor terhadap penerimaan dan pembagian dividen sebanding dengan kenaikan nilai modal, berarti setiap perusahaan yang memperoleh return on asset (ROA) di tahun berjalan harus membagikan dividen kepada investor.Hasil penelitian ini didukung oleh penelitian yang dilakukan oleh (Rahyuda et al., 2017), (Mubarok, 2016), (Ahmad dan Wardani, 2014) namun bertolak belakang dengan hasil penelitian yang dilakukan oleh (Parera, 2016) dan (Kurniawan et al., 2016) yang menyatakan bahwa ROA tidak berpengaruh terhadap DPR.

3) Pengaruh debt to equity ratio (DER) terhadap Dividend Payout Ratio (DPR)

Menurut tabel 4.2 variabel debt to equity ratio (DER) berpengaruh negatif dan tidak signifikan terhadap dividend payout ratio (DPR). Menurut (Brigham., 2014), kreditur akan melihat pada ekuitas, atau dana yang diperoleh sendiri, sebagai suatu batasan keamanan, sehingga semakin tinggi proporsi dari jumlah modal yang diberikan oleh pemegang saham, maka semakin kecil resiko yang akan dihadapi oleh kreditur. Hasil penelitian ini didukung oleh penelitian yang dilakukan oleh (Arilaha, 2009), (Sumiati et al., 2013) dan (Pamungkas et al., 2017) yang menyatakan bahwa debt to equity ratio (DER) tidak memiliki pengaruh yang signifikan terhadap dividend payout ratio (DPR).

4) Pengaruh Sales Growth (SG) terhadap Dividend Payout Ratio (DPR)

Menurut tabel 4.2 variabel sales growth (SG) berpengaruh negatif dan tidak signifikan terhadap dividend payout ratio (DPR). Hasil penelitian ini didukung oleh penelitian yang dilakukan oleh (Hamidah et al., 2014), (Kautsar, 2014) dan (Yulianti et al., 2016) yang menyatakan bahwa debt to equity ratio (DER) tidak memiliki pengaruh yang signifikan terhadap dividend payout ratio (DPR). 
Koefisien determinasi $\left(\mathbf{R}^{2}\right)$. Berdasarkan nilai adjusted $\mathrm{R}^{2}$ pada tabel 4.2 hasil uji common effect sebesar 0,205740 yang berarti 20,57\% dari variable current ratio (CR), return on asset (ROA), debt to equity ratio (DER), dan growth sales dapat menjelaskan keterkaitannya terhadap dividend payout ratio (DPR). Sedangkan sisanya sebesar 79,43\% dijelaskan oleh variabel-variabel lain diluar model penelitian.

\section{PENUTUP}

Simpulan. Pertama. Currrent ratio (CR) berpengaruh negatif dan tidak signifikan terhadap kebijakan dividen pada sub sektor farmasi dasn kosmetik periode 2012-2016. Kedua. Return on asset (ROA) berpengaruh positif dan signifikan terhadap kebijakan dividen pada sub sektor farmasi dan kosmetik periode 2012-2016. Ketiga. Debt to equity ratio (DER) berpengaruh negatif dan tidak sifgnifikan terhadap kebijakan dividen pada sub sektor farmasi dan kosmetik periode 2012-2016. Keempat. Sales growth (SG) berpengaruh postif dan tidak signifikan terhadap kebijakan dividen pada sub sektor farmasi dasn kosmetik periode 2012-2016.

Saran. Bagi Perusahaan. Dari hasil penelitian ini diperoleh ROA berpengaruh positif dan signifikansi. Hal ini berarti perusahaan harus meningkatkan ROA, karena semakin besar ROA menujukkan kebijakan dividen perusahaan yang semakin baik, yang akan mempengaruhi tingkat kesejahteraan dari investor. Meningkatkan ROA dilakukan dengan cara meningkatkan penjualan perusahaan dan meminimalkan biaya-biaya yang ada pada perusahaan, sehingga akan meningkatkan laba bersih perusahaan. ROA yang besar akan berdampak pada tingkat pengembalian investasi (dividend) semakin besar bagi investor.

Bagi Investor. Dari hasil penelitian ini diperoleh nilai signifikansi ROA sebesar 0,063. Hal ini berarti bagi investor (pemegang saham) yang hendak menanamkan modalnya untuk berinvestasi pada sub sektor farmasi dan kosmetik tidak perlu khawatir karena nilai ROA yang berpengaruh signifikan akan berdampak pada tingkat pengembalian investasi (return) semakin besar yaitu pendapatan dividen.

Untuk peneliti berikutnya, jika dilihat dari Adjusted $\mathrm{R}^{2}$ yang tergolong kecil yaitu $20,5740 \%$ dari variable-variabel independen yang ada pada penelitian mempengaruhi variable dependen, sehingga 79,426\% lainnya dipengaruhi oleh variable lain di luar penelitian. Sebaiknya variabel penelitian ditambahkan, serta juga menambahkan periode penelitian, mengingat investor lebih melihat prediksi jangka panjang dibanding prediksi jangka waktu yang relatif pendek. Dan juga ada baiknya jika menambahkan variabel lainnya seperti return on equity (ROE), cash ratio dan quick ratio, total asset turnover ratio (TATO), earning per share (EPS), free cash flow (FCF), net profit margin (NPM), agar dapat meningkatkan nilai Adjusted $\mathrm{R}^{2}$.

\section{DAFTAR RUJUKAN}

Afrina, Tika \& Triyonowati. (2014). Pengaruh Current Ratio, DER Dan ROA Terhadap DPR Perusahaan Rokok di BEI. Jurnal Ilmu \& Riset Manajemen, 3(9), 1-18. 
Ahmad, Gatot Nazir \& Wardani, Vina Kusuma. (2014). The Effect Of Fundamental Factor To Dividend Policy: Evidence In Indonesia Stock Exchange. International Journal of Business and Commerce, 4(2), 14-25.

Ahmed, Ibrahim Elsiddig. (2015). Liquidity, Profitability and the Dividends Payout Policy. World Review of Business Research, 5(2), 73-85.

Alzomaia, Turki SF \& Al-Khadhiri, Ahmed. (2013). Determination of Dividend Policy: The Evidence from Saudi Arabia. International Journal of Business and Social Science, 4(1), 181-192.

Arilaha, Muhammad Asril. (2009). Pengaruh Free Cash Flow, Profitabilitas, Likuiditas, Dan Leverage Terhadap Kebijakan Dividen. Jurnal Keuangan dan Perbankan, 13(1), 78-87.

Aqel, Saher. (2016). An Empirical Investigation of Corporate Dividend Payout Policy in an Emerging Market: Evidence from Palestine Securities Exchange. Research Journal of Finance and Accounting, 7(6), 7-16.

Badu, Ebenezer Agyemang. (2013). Determinants of Dividend Payout Policy of listed Financial Institutions in Ghana. Research Journal of Finance and Accounting, 4(7), 185-190.

Brigham, Eugene F \& Houston, Joel F. (2014). Dasar-Dasar Manajemen Keuangan Buku 1 dan 2. Edisi 11. Jakarta: Salemba Empat.

Brealey, Myers dan Marcus. 2013. Dasar-Dasar Manajemen Keuangan Perusahaan. Jilid 2. Edisi 5. Jakarta: Erlangga.

Darmayanti, Ni Kadek Desi \& Mustanda, Ketut. (2016). Pengaruh Pertumbuhan Penjualan, Jaminan Aset, Dan Ukuran Perusahaan Terhadap Kebijakan Dividen Pada Sektor Industri Barang Konsumsi. E-Jurnal Manajemen Unud, 5(8), 49214950.

Deitiana, Tita. (2009). Faktor-faktor yang mempengaruhi kebijakan pembayaran dividen kas. Jurnal Bisnis dan Akuntansi, 11(1), 57-64.

Dewi, Siska Christianity. (2008). Pengaruh kepemilikan manajerial, kepemilikan institusional, kebijakan hutang, profitabilitas dan ukuran perusahaan terhadap kebijakan dividen. Jurnal Bisnis dan Akuntansi. 10(1), 47-58.

Ghozali, Imam. (2013). Aplikasi Analisis Multivariate Dengan Program IBM SPSS 21. Semarang: Badan Penerbit Universitas Diponegoro.

Hanafi, Mamduh \& Abdul Halim. (2012). Analisa Laporan Keuangan. Edisi 4 cetakan ke2. Yogyakarta: UPP STIM YKPN.

Issa, Ayman I. F. (2015). The Determinants of Dividend Policy: Evidence from Malaysian Firms. Research Journal of Finance and Accounting, 6(18), 69-86.

Kasmir. (2014). Analisis Laporan Keuangan. Cetakan ke-7. Jakarta: PT.Raja Grafindo Persada.

Keown, Arthur J., John D. Martin \& J. William Petty. (2010). Foundation of Finance The Logic and Practice of Financial Management. Edisi ke-10. England: Pearson Education Limited.

Khan, Mula Nazar., Naeem, Muhammad Umair., Rizwan, Muhammad., Salman, Muhammad (2016). Factors Affecting the Firm Dividend Policy: An Empirical Evidence from Textile Sector of Pakistan. International Journal of Advanced Scientific Research and Management, 144-149.

Jurnal Ekonomi/Volume XXIV, No. 01 Maret 2019: 31-45

DOI: http://dx.doi.org/10.24912/je.v1i1.451 
Khotimah, Chusnul \& Waryati, Sri Yuli. (2015). Analisis Pengaruh Cash Position, Debt To Equity Ratio, dan Return On Assets Terhadap Dividend Payout Ratio Pada Perusahaan Manufaktur Yang Terdaftar di PT. Bursa Efek Indonesia Periode: 2010 2013. Jurnal Bisnis dan Ekonomi, 6(1), 30-46.

Maladjian, Christopher \& Rim El Khoury. (2014). Determinants of the Dividend Policy: An Empirical Study on the Lebanese Listed Banks. International Journal of Economics and Finance, 6(4), 240-256.

Malik, Fakhra., Gul, Sajid., Khan, Muhammad Tauseef., Rehman, Shafiq Ur and Khan, Madiha (2013). Factors Influencing Corporate Dividend Payout Decisions of Financial and Non-Financial Firms. Research Journal of Finance and Accounting, 4(1), 35-46.

Manneh, Marwan Abu \& Naser, Kamal. (2015). Determinants of Corporate Dividends Policy: Evidence from an Emerging Economy. International Journal of Economics and Finance, 7(7), 229-239.

Mardiyati, Umi., Nursati, Destyarsah dan Hamidah (2014). Pengaruh Free Cash Flow, Return On Assets, Total Assets Turnover dan Sales Growth Terhadap Dividend Payout Ratio (Studi Pada Perusahaan Manufaktur Yang Terdaftar Di Bursa Efek Indonesia Periode 2008-2012). Jurnal Riset Manajemen Sains Indonesia, 5(2), 204221.

Marlina, Lisa \& Danica, Clara. (2009). Analisis Pengaruh Cash Position, Debt To Equity Ratio, Dan Return On Assets Terhadap Dividend Payout Ratio. Jurnal Manajemen Bisnis, 2(1), 1-6.

Martono \& Agus Harjito. (2014). Manajemen Keuangan. Edisi 2. Yogyakarta: Ekonisia.

Mubarok, Nurul. (2016). Pengaruh Current Ratio, Debt To Equity Ratio, Total Asset Turnover Dan Return On Asset Terhadap Dividend Payout Ratio Pada Perusahaan Sektor Industri Barang Konsumsi Yang Terdaftar Di Bursa Efek Indonesia. IFinance, 2(2), 107-124.

Pamungkas, Noto., Rusherlistyani dan Janah, Isnatul (2017). Pengaruh Return on Equity, Debt to Equity Ratio, Current Ratio, Earning Per Share, dan Invesment Opportunity Set Terhadap Kebijakan Dividen. Jurnal Analisa Akuntasi dan Perpajakan, 1(1), 18 .

Pati, Agung Bayu \& Astika, Putra. (2016). Variabel-Variabel Fundamental Yang Berpengaruh Pada Kebijakan Dividen. E-Jurnal Akuntansi Universitas Udayana, 16(3), 1938-1964.

Rizqia, Dwita Ayu., Aisjah, Siti and Sumiati (2013). Effect of Managerial Ownership, Financial Leverage, Profitability, Firm Size, and Investment Opportunity on Dividend Policy and Firm Value. Research Journal of Finance and Accounting, 4(11), 120-130.

Ross, Stephen A., Westerfield, Randolph W., Jordan, Bradford D., Lim Joseph. Tan Ruth (2015). Pengantar Keuangan Perusahaan. Edisi Asia 1. Jakarta: Salemba Empat.

Saeed, Rashid., Riaz, Ayesha., Lodhi, Rab Nawaz., Munir, Hafiza Mubeen and Iqbal, Amber (2014). Determinants of Dividend Payouts in Financial Sector of Pakistan. Journal of Basic and Applied Scientific Research, 4(2) 33-42. 
Sharma, Dinesh Kumar \& Wadhwa, Ritu. (2017). Determinants of Dividend Policy Decision: An Analysis of Banks in India. Indian Institute of Technology Delhi, New Delhi, 617-623.

Sudana, I Made. (2015). Manajemen Keuangan Perusahaan. Edisi Kedua. Jakarta: Erlangga.

Sugiyono. (2015). Statistika Untuk Penelitian. Cetakan ke-26. Bandung: Alfabeta.

Tahu, Gregorius Paulus., Wiagustini, Ni Luh Putu., Rahayu, Henny (2017) Anteseden Dividend Policy on Manufacturing Industry in Indonesia Stock Exchange. Research Journal of Finance and Accounting, 8(18), 99-113.

Urhoghide, Ruth Osaretin \& Ojeme, Samuel Samson. (2016). Effect of Mergers and Acquisitions on the Determinants of Dividend Payout in Nigeria. Research Journal of Finance and Accounting, 7(2), 27-36.

Van Horne, James C dan. Wachowicz, Jr. John M (2013). Fundamentals of Financial Management, Prinsip-prinsip Manajemen Keuangan 2. Edisi 13. Jakarta: Salemba Empat.

Widjarjono, Agus. (2013). Ekonometrika: Pengantar dan Aplikasi. Edisi ke 4. Yogyakarta: UPP STIM YKPN.

Yanti. (2014). Analisis Faktor Yang Berpengaruh Terhadap Kebijakan Dividen Payout Ratio Pada Perusahaan Manufaktur Yang Terdaftar di Bursa Efek Indonesia. Jurnal TEKUN, 5(2), 306-320.

www.idx.co.id

www.bps.go.id

www.mandiri-institute.id

www.kimiafarma.co.id

www.mediaindonesia.com

www.antaranews.com 